\title{
THE CLASH OF THE EAST AND WEST IN MARYAM JAMEELAH'S AHMAD KHALIL: THE STORY OF A PALESTINIAN REFUGEE
}

Güllü ERMİŞ*

\begin{abstract}
This study analyzes two cultures that are in conflict on several aspects: The East and West. Religious, social, cultural differences are among these clashes. Yet, the conflict is not a natural and innate one. On the contrary, it is a result of imagined borders, prejudices, political and economical rivalries between the societies. Maryam Jameelah, formerly a Zionist and Jew, and then accepting Islam, is an insider to both civilisations. In her dealing the conflict she brings forth the differing values and cultural differences of the two societies and depicts the conflict. She concludes that it is not pertinent to values or cultural differences. The proximity of values and the cultures of the two have changed through time. Colonial penetration of the West to the East, modernity process condemning the East to the past and decadency hindering and stigmatizing the East also aggravated the clash. In "Ahmad Khalil" the conflict between the Zionists and Palestinians is told by Maryam Jameelah. She depicts that Zionism is an extension and amalgamation of this one-sided and constructed process that is dividing the world. As Joe Kovel says Zionist nationalism became not the restoration of a land but the establishment of Jewish colonial control over that land, and coordinatively the elimination of its indigenous inhabitants. Regina Sharif believes that this bad idea is nurtured in the west and supported by non- Jewish people of Europe on the basis of interest. The acceptance of the idea does not stem from compassion towards Jewish people.
\end{abstract}

Key Words: East, West, Zionism, Islam, Conflict, New Historicism, Nationalism, Imagined Communities, Memory.

\section{MERYEM CEMILE'NIN AHMET HALİL ADLI ESERINDE DOĞU-BATI ÇATIŞMASI}

Özet

Bu çalışma, çeşitli açılardan çatışan iki kültürü analiz etmektedir: Doğu ve Batı. Bu çatışmalar arasında dini, sosyal, kültürel farklılıklar yer almaktadır. Ancak, çatışma doğal ve doğuştan gelen bir çatışma değildir. Aksine, toplumlar arasındaki hayali sınırların, önyargıların, siyasi ve ekonomik rekabetlerin bir sonucudur. Önceleri Siyonist ve Yahudi olan ve daha sonra İslam'ı kabul eden ve Pakistan'a yerleșip orda yaşayan Maryam Jameelah, her iki medeniyetin de içindendir. Çatıșmayı ele

* Öğr. Gör., Bingöl Üniversitesi Yabancı Diller Yüksekokulu, İngilizce Bölümü, germis@bingol.edu.tr ORCID: 0000-0001-9971-3446

(Makale Gönderim Tarihi: 18.12.2021-Makale Kabul Tarihi: 21.12.2021) DOI: https://doi.org/10.53440/bad.1038202 
alırken iki toplumun farklı değerlerini ve kültürel farklılıklarını ortaya koyar ve çatışmayı tasvir eder. Çatışmanın değerlerle veya kültürel farklılıklarla ilgili olmadığı sonucuna varır. İkisinin değerlerinin ve kültürlerinin yakınlığı zamanla değiştiği kanısındadır. Batı'nın Doğu'ya sömürgeci sızması, Doğu'yu geçmişe mahkûm eden modernite süreci ve Doğu'yu engelleyen ve damgalayan çürümüşlük algısı çatışmayı şiddetlendirmiştir. "Ahmad KHalil" Siyonistler ve Filistinliler arasındaki çatışmayı ele alır. Siyonizmin dünyayı bölen bu tek taraflı ve inşa edilmiş sürecin bir uzantısı ve karıșımı olduğunu gösterir. Joe Kovel'in dediği gibi Siyonist milliyetçilik, bir toprağın restorasyonu değil, o topraklar üzerinde Yahudi sömürge otoritesinin kontrollü bir şekilde kurulması ve yerli sakinlerinin ortadan kaldırılmasıdır. Regina Sharif, bu kötü fikrin Batı'dan beslendiğine ve Avrupa'nın Yahudi olmayan halkları tarafından çıkar temelinde desteklendiğine inanır. İsrailin Filistin'e yerleştirilmesi, Yahudilere karşı şefkatten kaynaklanmaz.

Anahtar Kelimeler: Doğu, Batı, Siyonizm, Sömürgecilik, İslam, Çatışma, Yeni Tarihselcilik, Milliyetçilik, Hayali Cemaatler, Hafıza.

\section{Giriş}

In a time that there can be hope for the people of the world to gain awareness towards each other still we hear the call of clash from those who hold and fear to lose power. Samuel Huntington in The Clash of Civilizations declared that "The most important conflicts of the future will occur along the cultural fault lines separating the civilizations from one another." ${ }^{11}$ Despite his confession that "Differences do not necessarily mean conflict, and conflict does not necessarily mean violence" ${ }^{2}$, he is adamant that "Over centuries, differences among civilizations have generated the most prolonged and the most violent conflicts." ${ }^{3}$ Such discourses are barriers set between people to control better and preserve the age-long prejudices and enmities that are fed throughout ages.

Binnaz Toprak says that a world of dual-nucleus is a comfortable world for both social scientists and politicians. It is divided into two categories, "we" and "others", with a simple and understandable classification. The concept of "East" has come into existence when Europe which is an extension of Asia has described itself as "West" ${ }^{4}$ Religious, cultural and political threats caused

1 Samuel P. Huntington, The Clash of Civilizations and Remaking of World Order, Penguin Books, 1996, p.25.

2 Huntington, p.25.

3 Huntington, p.25

4 Ibrahim Kalın, Ben, Öteki ve Ötesi, İnsan Yayınları, 2016, p. 17. 
the mapping of this division; they emerged gradually and hardened in time. The division coincides with the emergence of Islam as a threat to European countries. ${ }^{5}$ As Edward Said suggests "Doubtless Islam was a real provocation in many ways. It lay uneasily close to Christianity: Geographically and culturally. It could boast of unrivaled military and political successes. The Islamic lands sit adjacent to and even on the top of the Biblical lands." 6 This caused a contest between the East and the west but it turned into enmity. The fear of yoke has ended in extremism, oppression and disregarding of the other.

\subsection{East in the Eyes of the West}

Sardar and Davies point out that Europe found Islam at its borders, and Islam became a political problem. ${ }^{7}$ To them the image mongering was born in ignorance, forged by military and political domination and nourished by racial superiority, religious bigotry and blind faith in the dogmatic assumption that Occidental civilization is the norm for all human cultures. ${ }^{8}$ The result of this superiority for the East is paralysis as it changed the structure of traditional societies fundamentally and this encounter has caused the majority of Asian creative powers to be paralyzed. ${ }^{9}$ The clash is not a brand-new phenomenon besieging us it is part of this history, and contrary to the belief that its cause is cultural and based on values; actually, it is based on the divisive practices of policy makers that impose a unilateral view of the West over non- western people.

Maryam Jameelah, born in New York city, was a third generation German Jew and a Zionist who converted to Islam after a long search to find meaning in life. She says it is discrepancies she realized in orientalist sources and his society directed her to search for the truth for herself. She has an insider and outsider position which provides her to delve into the conflict in a broader and deeper way. She compares the two societies on the basis of their conflicting areas and concludes that differences would not produce conflicts if it had not been for injustices, one dimensional reading of the societies, and power relations. She searches for a way for both societies to co-exist instead of oppression and denial.

5 Binnaz Toprak, "Huntington, Batı' nın Önyargılarını Yansıtıyor"in Samuel P. Huntington v.d. Medeniyetler Çatıșması compiled by Murat Yılmaz, Vadi, p. 388.

6 Edward Said, Şarkiyatçılık, Batı́nın Şark Anlayışları, Metis, 1999, p, 72.

7 Ziauddin Sardar\& Merryl Wyn Davies, Distorted Imaginations, Grey Seal Books, 1990, p. 17.

8 Sardar\& Davies, p.17.

9 Daryuş Şayegan, Batı Karşısında Asya, Ağaç Kitabevi Yayınları, 2005, p. 270. 


\subsection{Culture of Colonialism and Imperialism and Dignity of the East}

The cherished values of these societies are different. The way of relations between the two is determined mostly by unyielding worship of freedom and inexorable disregarding and disrespect to dignity. Mazrui says that the West sacrificed the East for the sake of its own interest and ignored the most cherished values of the East. "If the Western world has a nexus of liberty, their centres in the course of the 20th century become the United States. The Muslim World has always had a nexus of dignity- and the centre of the Muslim world has for centuries been the Middle East."10 Mazrui adds "The Americans saw their anti-colonialism as a defence of liberty everywhere. But the fight against European colonialism and racism was above all a struggle for human dignity." For instance, "A Jewish state had been created in a region that for a thousand years had been overwhelmingly Muslim. What is more, it was created in ways that violated dignity. There was an ethnic cleansing which displaced thousands of Palestinians to make room for Jews." ${ }^{11}$ Furthermore, “...just when European colonialism and occupation of Arab and Muslim lands was coming to an end, an alien expansionist power was created in the heartland of the Arab nation. What is more, the Jewish state was protected by the West from the odium of being called either colonialist or imperialist"12. The dignity of Palestinian people is sacrificed to the freedom which disregard the existence of another people. "Zionist propaganda is based on the premise that their right to Palestine is justified as the Jews are white Europeans representing the progressive west who have developed Palestine into a prosperous modern state while during the rule of Arabs it was a poor and backward country."13

Jameelah relates the Nazi massacres, and its mentality with the Zionist crimes and ethnic cleansing in Palestine as both of them are based on differentiation of people. She expresses that under the rule of Adolf Hitler the Aryans are educated to degrade the Jews as sub- human. Jews are regarded not as human but as vermin like rats and lice. She says "this relegating of inferior races like Jews and Gypsies, to a sub- human status was the motivation for all the dreadful crimes the Nazis committed against them. I have no doubt that the Zionists and their supporters have adopted the identical attitude against the Arabs and the Muslims."14

10 Mazrui, Ali, Islam Between Globalization and Counterterrorism, Oxford, James Currey, 2006, p.77.

11 Mazrui, p.78.

12 Mazrui, p.78

13 Maryam Jameelah, Ahmad Khalil, The Story of an Arab Refuge, Muhammed Yusuf Khan\&Sons, revised version, 2000, p.ix.

14 Jameelah, Ahmad Khalil, p.ix. 
Dispute over territory and memory is another conflicting area. The occupation of Palestine is triggered with a historical memory provided by national historiography. Zionists together with the west believed that Palestine was an empty and uncultivated land that the Jewish settlers wrestled from a primal state of nature, in any case since they were merely wandering nomads; that even if the natives were dispossessed, they themselves were principally to blame since it was they who greeted the well-intentioned settlers with swords that then 'rebounded against them'. ${ }^{15}$ Yet, Cleary says that hostility of Palestinian people is not baseless but has its origins in a history of dispossession, a history again repeated when 'the Camel's Field' is seized. ${ }^{16}$

Palestinian people living in Palestine through centuries are disregarded and expected to forget and leave it. Said says, "behind every Palestinian, there is a great general fact that he once so long ago lived in a land of his own called Palestine, which is no longer his homeland." 17 Every person has his own trauma on the same theme. ${ }^{18}$ Ahmad Khalil misses his village and visits it. He wonders "what happened to his home, his village and his family belongings they had not been able to take with them into exile." ${ }^{19}$ He misses being there again, to visit the graves of his grandfather, his mother, his uncle, Yusuf Malik and his cousin, Abdul Aziz. ${ }^{20}$

Ahmad Khalil even thinks to live under the Jewish rule for the sake of remaining in his village "... if only they would leave him alone, it would be no worse than the British." 21 Noam Chomsky and Ilan Pappe say that the intentions of the Zionist were not to come and live in peace with the Palestinians the missing part is the chapter of ethnic cleansing that began in 1948 to onwards. ${ }^{22}$ They say that "This was the principal strategy of the Judaization of Palestine." 23 Ahmad Khalil and his cousin were told their village was blown up with dynamite soon after the war and it was now the town of Yad Mordecai. ${ }^{24}$ They saw their childhood erased by the colonists. "How could

15 Joe Cleary, Literature, Partition, and the Nation-State, Cambridge University, 2014, p.163164.

16 Cleary, p.163-164

17 Edward Said, The Question of Palestine, Vintage Book, 1992, p.115.

18 Said, The Question of Palestine, P.115.

19 Jameelah, Ahmad Khalil, p.137.

20 Jameelah, Ahmad Khalil, p.137.

21 Jameelah, Ahmad Khalil, p.137.

22 Noam Chomsky and llan Pappe, Gaza in Crisis: Reflections on Israel's War Against the Palestinians, edited by by Frank Barat, Haymarket Books Chicago, Illinois, 2010, p.62.

23 Chomsky\& Pappe., p.64.

24 Jameelah, Ahmad Khalil, p.138. 
he persuade them even if he could speak Hebrew, even if he were the most eloquent orator who ever lived there that this house was his? And that they have no right to be here?" He deplores that "All he possessed had been taken from him and there seemed no hope of ever reclaiming it back." ${ }^{25}$

By means of ethnic cleansing, renaming, by building fences and walls the Zionists want to destroy the existence of Palestinians. Ilan Pappe discusses that Palestinians were not aware of the true nature of Zionism. Although the land changed hands "However, the peoples' lives had continued more or less unchanged: they toiled the land or conducted their trade wherever they were, and quickly resigned themselves to the new situation until it changed once again." 26 Pappe adds that "Hence, villagers and city dwellers alike waited patiently to see what it would mean to be part of either a Jewish state or any other new regime that might replace British rule. Most of them had no idea what was in store for them, that what was about to happen would constitute an unprecedented chapter in Palestine's history: not a mere transition from one ruler to another, but the actual dispossession of the people living on the land."27

\subsection{The Question of Violence}

Huntington attributes terrorism and violence to the East while in the West the rule of democracy and enlightenment prevails. ${ }^{28} \mathrm{He}$ argued that the East is more aggressive than any other civilisation in the world and there is more violence in the lands of the East. Mazrui criticises that "Huntington does not distinguish between the situations where Muslims are primarily victims (as in Chechenya, Kashmir and Palestine) and situations in which Muslims are primarily perpetrators (as in Sudan). In those cases, where Muslims are in rebellion against... collective indignity. This is true of rebellions of Muslims in Chechenya, Palestine, Kasmir, Kosova, and even Nigeria."29 Mazrui argues that the East is condemned intentionally to a place where terrorism proliferates. He discusses that President George W. Bush use of macho language of ultimatum and no negotiation over surrendering Usammah bin Laden do bred terrorism. To him Taliban was not allowed a line of dignified retreat. "Bush was trying his best to get the Taliban to say 'No' to the request for the head of Usmah bin Laden so that Bush could embark on his long-awaited military action." ${ }^{30}$

25 Jameelah, Ahmad Khalil,p.139.

26 Ilan Pappe, Ethnic Cleansing of Palestine, One-Word pub. 2006, p.50.

27 Pappe, p.50.

28 Huntington, The Clash of East and The West, 2006, p.69-71.

29 Mazrui, Islam Between Globalization and Counterterrorism, p.76.

30 Mazrui, p.76 
The portrayal of the East in a negative way provided the psychological drive both for the West and the Zionists resulting in clashes. Herzl argues '[w] e should there form a portion of a rampart of Europe against Asia, an outpost of civilization as opposed to barbarism'. Decades later, Chaim Weizmann invoked a similarly Manichean cartography when he described the Jewish settlement in Palestine in terms of an elemental conflict between civilization and chaos: 'On the one side, the forces of destruction, the forces of the desert, have arisen, and on the other side stand firm the forces of civilization and building.' 31

The discourse of aggressive Arab both provided the motivation for inhumanly attitude to the Palestinians and under the pretext of security the creeping settlements and confiscation of land. Gregory Derek points out the inhumanly attitude and the slanders that directed at the Palestinians to justify the occupations and says "Israel's was founded on brute force, repression and fear, collaboration and treachery, beatings and torture chambers, and daily intimidation, humiliation and manipulation." ${ }^{32}$ Ahmad Khalil and his cousin are called as "the Black Beast" when they give harm to the machinery of the colonists. "They sized A. Khalil and stripped him naked and took terms beating him with sticks, clubs and butt- ends of their rifles until the blood flowed." ${ }^{33}$ As he did no confess "salt was poured on the wounds and the beating resumed of afresh. He screamed for water and they poured a bucket of urine over him..." ${ }^{34}$ They dumped him on the sand as a warning to the refugees. ${ }^{35}$

Although the Zionists are portrayed as the victims of the Palestinians and as the force of enlightenment against the oriental darkness contrarily as it is also depicted by Sharif "Again and again during its short history of existence as an independent state, Israel has demonstrated its military might and superiority over its Arab neighbours. It's Israel's superior military strength carefully nurtured by its Western allies that threatens its neighbours, not the reverse, as Israel wants us to believe." ${ }^{36}$ She believes that the biblical analogy of David and Goliath is for expansion and consolidation of the Jewish state. Sharif explains that

\footnotetext{
31 Cleary, p.151.

32 Derek Gregory, The Colonial Present, Blackwell, 2004, p.54.

33 Jameelah, Ahmad Khalil, p.134.

34 Jameelah, Ahmad Khalil, p.134

35 Jameelah, Ahmad Khalil, p.134-35.

36 Regina Sharif, Non- Jewish Zionism: Its Roots In Western History, Zed Press, 1983, p.140.
} 
"The events in Lebanon in 1982 provided a decisive and authoritative contribution to the demystification of the myth of Israel as the brave, helpless, little David, surrounded by millions of vengeful Arabs. Yet, due to their political disunity and military weakness, the Arabs have never even come close to being a 'Goliath', President Reagen himself recognized this and stated it during a National Security Council meeting: 'Israel is no longer David. It is Goliath."37

Mazrui criticises that Western democracies despite all enlightenment bred terrorism. To kill Usameh bin Laden do not end terrorism as there was international terrorism before al- Qaeda and Osama bin Laden. And there may continue to be such terrorism longer after him if the causes of international terrorism are not addressed. ${ }^{38}$ On this aspect there is a shared underdevelopment between the two civilisations. "Human rights are being devoid to many detainees simply because they are not American yet there are even American citizens detained without access to lawyers" and so "The U.S. has undergone a sudden and disturbing spasm of underdevelopment." As for the East "Much of its underdevelopment continues to be fundamentally economic."39

Mazrui says that the measure of cultures is not only their virtues. Historically, the religion and the civilisation have been resistant to forces that contributed to the worst aspects of the $20^{\text {th }}$ century's interludes of barbarism: racism, genocide and violence within society. Mazrui expresses that "Terrorism is not child of evil, yet it is a child of rage, frustration and despair." ${ }^{40}$ Despite the discourse that refutes their rights, Jameelah indicates, Palestinian people resist the injustice. Thus, Malek Wahab says "You will never rule over us. Nothing here belongs to you! This land is ours. Return to us our fields, our spring of pure water, our stolen horse, camels, our flocks and give us just compensation for all the property taken from us by the illegal immigrants against our consent and then you can go back to your homeland across the sea in peace..." 41

\subsection{Politics and Ideology}

Mazrui says that there was a tripartite division of world in Muslim world once: Dar al-Harb, Dar al- Islam and Dar al-Sulh. This division is employed by the West, too. Yet, it turned the entire world into Dar al-Harb. ${ }^{42}$ "Western

37 Sharif, p.140.

38 Mazrui, Islam Between Globalization and Counterterrorism, p.28-29.

39 Mazrui, p.29.

40 Mazrui, p.25.

41 Jameelah, Ahmad Khalil, p.106.

42 Mazrui, Islam Between Globalization and Counterterrorism, p.15. 
democracies continue to back state terrorism by propping up repressive and terrorist regimes" and adds that Western democracies depicts their anti- terrorist view only for the sake of themselves and their allies. They disregard the inhibitions of the international law and "use means against the terrorism which are totally disproportionate to the threat, they risk in increasing the very anarchy in which terrorists flourish. ${ }^{43} \mathrm{He}$ argues that there is a highly selective use of the word "terrorism". According to western usage, it is not terrorism if you kill innocent civilians provided you yourself wearing a uniform, driving a tank and sparing your own life. However, it is terrorism if you are prepared to blow yourself up and are not wearing a uniform and you also kill innocent civilians of the other side. ${ }^{44}$ "Ahmad Khalil was startled by the screaming of frantic women and terrified children. A giant covered truck was parked in front of the door. A dozen soldiers clad in khaki uniforms and armed with machine guns tumbled out." ${ }^{45}$ Mazrui elucidates that both terrorism and its cause is globalized currently as frustrations and desperations of people affected by decisions made in Washington, New York, Paris, London and Moscow. "A global coalition against terrorism makes sense only if it included addressing its causes." 46 For instance, in Israeli-Palestinian conflict he believes that the U.S. is too pro-Israeli to be a honest broker ${ }^{47}$ and asks that "are not the Israeli settlement on the occupied land illegal and tantamount to belligerency." 48

Although it is regarded a war that is started and lost by the Palestinians. Jameelah depicts the belligerent occupation of the Palestine by the Zionists. Ahmad Khalil saw that the streets were filled with soldiers and people pulling their belongings and baggages onto huge buses and trucks." ${ }^{49}$ Their faces were filled with horror. As Ilan Pappe argued, during the ethnic cleansing of Haifa defenceless Palestinians were so perplexed and terrorized that "without packing any of their belongings or even knowing what they were doing, people began leaving en masse." 50

Palestinians were expelled from the areas where there was no fighting, where there were local ceasefire, or where fighting had long came to an end,

43 Mazrui, p.53-54.

44 Mazrui, p.75.

45 Jameelah, Ahmad Khalil, p.105.

46 Jameelah, Ahmad Khalil, p.54.

47 Jameelah, Ahmad Khalil, p.59.

48 Jameelah, Ahmad Khalil, p.60.

49 Jameelah, Ahmad Khalil, p.94.

50 Ilan Pappe, Ethnic Cleansing, p.95. 
and that the vast majority were not permitted to return to their homes even after the fighting was over. ${ }^{51}$ This has been enforced for the violent removal of a people from a country, in order to create new demographic, and therefore national, realities. ${ }^{52}$ It is what today would be called "ethnic cleansing," it is called "transfer" or some other sanitized and neutral designation. ${ }^{53}$

Kovel says that the Zionists were not merely in search of finding a homeland and take a refugee there, in contrast; Palestine was a magical place that had to be possessed by no one but only by the Jews. ${ }^{54}$ So, contrary to the popular belief, the Zionist had no intention of living in peace side by side with their Arab hosts. ${ }^{55}$ As Dubnow puts it "The ultimate goal is, in time, to take over the Land of Israel and to restore to the Jews the political independence they have been deprived of for these two thousand years ... The Jews will yet arise and, arms in hand (if need be), declare that they are the masters of their ancient homeland." ${ }^{56}$ In order to achieve this says Ben-Yehuda "The thing we must do now is to become as strong as we can, to conquer the country, covertly, bit by bit ... We can only do this covertly, quietly. ..."57 To make it happen "We will not set up committees so that the Arabs will know what we are after, we shall act like silent spies, we shall buy, buy, buy."58

The East is condemned for its endeavour of Jihad as it is evaluated to kill and bomb randomly. "Contrary to popular Western perceptions, it does not mean 'holy war'. But it does mean 'sacred struggle'. The struggle can be armed struggle or peaceful striving, a struggle against others or against the demons in oneself, a physical struggle or an other-regarding confrontation. A struggle in the path of God (fi sabili'lah) can be Jihad for peace rather than the establishment of an Islamic state, for example."59 Wars are initiated against evil and only when it is inevitable, not against civil people and for pleasure. Ilan Pappe depicts that Palestinian villages were set a fire where there is no resistance and counter attack. He says that indeed, the Palestinian people were preserving their normal life which was a source of astonishment and irritation for the Zionists who were in search of a trigger to begin the land

51 Rashid Khalidi, The Iron Cage: The Story Of The Palestinian Struggle For Statehood, One World, 2006, p.4.

52 Khalidi, p.5.

53 Khalidi,

54 Kovel, Overcoming Zionism, p.38.

55 Kovel, p.38

56 Kovel, p.45.

57 Kovel, p.45.

58 Kovel, p.45.

59 Mazru, Islam Between Globalization and Counterterrorism, p.82. 
expropriation. "In any case, after three days, foreign reporters observing the demonstration and strikes detected a growing reluctance among common Palestinians to continue the protest and, noted a clear desire to return normalcy... Most of them had no idea what was in store for them, that what was about to happen would constitute an unprecedented chapter in Palestine's history: not a mere transition from one ruler to another, but the actual dispossession of the people living on the land." ${ }^{60}$ On his last speech Yusuf Malik advices to the people and says "We are not with bloody racist deceived by the nationalists who are as godless and unscrupulous as our enemy and struggle with the same cruelty and ruthlessness only for this bit of land and nothing more. Our fight is Jihad to attain salvation from Allah and peace in the world to come..." 61 Thus he says "We fight not only for our homes and country against foreign rule but much more for what we know is the sacred and eternal truth to combat the evil ways they seek to impose upon us against our will..." ${ }^{62}$ They are also fighting against subjugation. "Even if the lrgun tries to repeat the massacre of Deir Yasin here, we will not flee like frightened sheep or dumb cattle. We will stay on and fight."63

Though the conflict is regarded as Arab aggression, Khalidi preserves that such a reading obscures the truth. He argues that the popular discourse of aggressive Arab used instead of accepting the fact that it is a civil war in which the weaker side lost unremittingly. It ends in with significant gains of territory for the Jewish state and concomitant expulsions of the Arab population: during each phase, several hundred thousand Palestinians fled their homes."64

Bad conscience rules the violence of the Zionists; it is the engine behind the celebration of the violence on the basis of celebration of a past stripped of responsibility. Kovel says that such a mind is not whole and in peace, it is a bad conscience. He expresses that "The language of Zionism is a rendering of the dialects of Judaism into a singular power-form, and with a big army behind it, an army not just military but also a very large apparatus within state and civil society, staffed by new Jews, who are not simply Jews, therefore, but power-Jews, Jews whose sincere devotion to Israel is also a sincere attachment to the pillars of empire." 65 To him this bad conscience could be

60 Pappe, Ethnic Cleansing of Palestine, p. 50.

61 Jameelah, Ahmad Khalil, p.111.

62 Jameelah, Ahmad Khalil, p.111.

63 Jameelah, Ahmad Khalil, p.111.

64 Khalidi, p.4.

65 Kovel, p.133. 
achieved only by taking responsibility. He regards it as a human weakness and that no man is an Island. What is done to the Palestinian people is unjust the bad conscience that sovereign over it makes its dissolution impossible. Kovel says "recognition of common humanity and acceptance of moral responsibility lead reconciliation and forgiveness." 66

Mazrui criticises that the reason of the clash is not different values yet homogenisation of globalisation and hegemonisation as a result of it. ${ }^{67}$ Jameelah expresses that for nearly five centuries the white man justified his imperialist ambitions and colonial expansion on the basis of his superior civilization and the native backwardness which glorified every atrocity and injustice. ${ }^{68}$ So Jameelah says "It is not surprising therefore to find Zionist propaganda employing the identical argument to glorify the Jewish colonization of Palestine and the dispossession of the indigenous population there." 69 Thereby says Jameelah, by paraphrasing Judaism as A Civilization by Kaplan, with Balfour Declaration this mission is burdened on the Zionists to advance the kingdom of God on earth as they are regarded as having the right and the means to emerge as the bearer of a noble mission." ${ }^{\prime 7}$

In view of Mazrui America holds three engines of globalisation that ends in hegemony: economy, communication technologies, empire. They ended in villagization of the world and emergence of one superpower as a security system for the globe. ${ }^{71}$ The West has not achieved globalisation in religion. Islam is a threat on this aspect and a challenge for the West as a result. Mazrui discusses that the East with Islam and its Universalist message contains in itself a challenge to the West. ${ }^{72}$ So, "Clashes are wars of images and the control of opinions in this hegemonic phase."73

Mazrui comments that "Westerners tend to think of Islamic societies as backward looking, oppressed by religion, an inhumanly governed, comparing them to their own enlightened, secular democracies." ${ }^{74}$ He states that contrary to the supposition that distance is narrower than they assume. "Islam is not just a religion, and certainly not just a fundamentalist political

\footnotetext{
66 Kovel, p.158.

67 Mazrui, p.15.

68 Jameelah, Westernization and Muslims, p. 42.

69 Jameelah, Westernization and Muslims, p. 42.

70 Jameelah, Westernization and Muslims, p.44.

71 Mazrui, p.72.

72 Mazrui, p.72.

73 Mazrui, p.72.

74 Mazrui, p.243.
} 
movement. It is a civilisation and a way of life that varies from one Muslim country to another but is animated by a common spirit far more humane than most Westerners realize. Nor do those in the West always recognize how their own societies have failed to live up to their liberal mythology. Moreover, aspects of Islamic culture that westerners regard as medieval may have prevailed in their own culture until fairly recently, in many cases, Islamic societies may be only a few decades behind socially and technologically advanced Western ones."75

\subsection{Cultures in Conflict}

Jameelah examine the conflict of the values, most of which are though attributed to the East and peculiar to the East but previously celebrated by both of the civilisations though they are in the process of passing into oblivion in the West a result of historical processes. One of the cultural divide is personal mores and family values. Mazrui expresses that the mores and family values have changed rapidly in America since the two world wars. "Premarital sex, for example, was strongly disapproved of in America in the 1920s. There was even law against sex outside marriage in some states, some of which may still be on the books but hardly ever enforced. Today sex before marriage, with parental consent, is common. This is more distant from Islamic values." ${ }^{6}$ Jameelah criticises that "a society which makes no cultural or social distinction between the sexes, a society without marriage, home and family, where modesty, chastity and motherhood are scorned, does not represent 'progress' or 'liberation' but degradation at its worst."77 For instance, premarital sex is forbiddedn in Islamic civilisation as it endangers the functioning family. Some Arab societies even have honour killing for daughters who stray sexually, though this principle is un- Islamic. ${ }^{78}$

Jameelah argues that "The greatest social achievement of the Prophet in Medina was precisely in breaking the existing tribal bonds and substituting religious ones which were connected on the one hand with the totality of the Muslim community and on the other hand with the family."79 As they complement one another it is given priority. Khadija's sister transgresses this priority and carries a secret affair with a soldier from Negba and she is seduced by him.

75 Mazrui, p.244.

76 Mazrui, p.293.

77 Jameelah, "Islam and Muslim Woman”, p. 17.

78 Mazrui, p.293.

79 Maryam Jameelah, "Islam and the Muslim Woman Today", Taj Company, Jama Masjid, Delhi, 1982, p. 17. 
It is regarded as betrayal by her father; he disowned her, insisting that she be buried in Negba instead. Her conduct is punished severely by Muslim society. "After the settlers had seen the two corpses, they never dared go anywhere near our woman again." 80 Such a conduct is intended to protect the society from the ills of individual. Jameelah criticises those who condemns Islam for death penalty. She criticises the sacrifice of the society to the whims of individual. She says that "sexual promiscuity has been directly responsible for the decline and fall of every nation in which these evils became prevalent."81

Another divide between the West and the East is the status of women. Ismail preserves western attitude towards Muslim woman. The woman is like a domesticated animal, who gets respect only in regard to the job she does, and she is a creature that replaced by another one upon her death. On the other side appears western image of woman who wants the household regard her as a guardian and homemaker. ${ }^{82}$ Ismail regards Muslim women as submissive, ignorant, imprisoned and also domestic servant. "I could not marry the old type of woman who is so submissive and ignorant of her rights. I cannot imprison my wife in the house for a lifetime... and make her veil herself in black...I want my wife as my life companion not a domestic servant producing another baby each year."83

Jameelah defends that the woman never had been degraded to such an extent throughout the ages by pointing out Hitler who humiliated her by diminishing her to the level of a machine giving birth to children, and socialism and capitalism that provided her taking part in the production of goods and business. ${ }^{84}$ She says that we don't believe that only economic conditions will change the women even if this condition is a basic and permanent one without the fulfilment of their moral, social and cultural needs the expected woman will not appear and this kind of woman exists nowhere today neither in Russia and France nor in America. ${ }^{85}$ She believes that emancipation of woman provided the mega industries the needed workforce and most of the women are working out of desperateness and as she has no other way in a world where money doesn't grow on trees. ${ }^{86}$

80 Maryam Jameelah, Ahmad Khalil, p.51

81 Jameelah, Islam and the Western Society, Adam Publishers \& Distributors, $3^{\text {rd }}{ }^{2}$ dition (1990), p.106.

82 Maryam Jameelah, Kendini Mahkum Eden Batı, Kültür Basın Yayın Birliği, 1990, p.202.

83 Jameelah, Ahmad Khalil, P.297.

84 Jameelah, Kendini Mahkum Eden Batı, p.203.

85 Jameelah, Kendini Mahkum Eden Batı, p.203.

86 Jameelah, Kendini Mahkum Eden Batı, p.203-207. 
In view of Jameelah modern woman has her hardships and dissapointments. She believes that as most of the girls lose faith in their boyfriends, firstly they become cynical and sarcastic who do not have faith in any value fall prey to lesbianism and homosexuality which to her are terrible problems. She calls these girls as twilight girls who lost their light as a result of the freedom they attained and as being stripped of all their sacred attraction. ${ }^{87}$

Mazrui criticises that on the issue of women's liberation both the West and the Muslim world were on the same stage of relative sexism early in the $20^{\text {th }}$ century but since then American culture on gender has become more and more different from Muslim culture on gender. On the positive side, American women are more active in the economy and in the political process have made enormous progress in the quest for equality. ${ }^{88}$ Yet, "On the negative side sexuality has been cheapened in America and female bodies are exploited in a wider range of ways than ever- from blue movies on television to techniques in advertising, from high-class prostitution to the legacy of mini-skirts and tight pants." 89 He believes that "While American culture does give greater freedom to women than does Muslim culture, American culture extends less dignity to women than do Muslim culture. Sons in America respect their mothers less than sons in the Muslim world; husbands in America respect their wives more than husbands in the Muslim world." 90

While the West supports the liberation of woman from home, veil, burdens at home and backing up her active partipation to the economy on the other hand; Islam gives her the role of mother, the protector of her house, the helper of her husband and wants to keep her away from the burden of gaining money. This position of Muslim woman is evaluated by the West as silent and oppressed. But Khadija succeeds in areas where women literary figures traditionally do not. In her relationship to the land, her strength as a mother/ nurturer figure for the entire village, and her ability to forge her own destiny. Khadija is a female figure rife with agency and power, the one who maintains the trauma, the one who incessantly prepared the same meals to his family and the one who strives hard in the fields to contribute her family. Khadija exceeds the Orientalist description as silent, passive. She is not victim of her society yet she is the victim of a wider campaign dissuading her from a comfortable life. "There was no food for those who do not work" which hints at

87 Jameelah, Kendini Mahkum Eden Batı, p.214.

88 Mazrui, p.293.

89 Mazrui, p.293.

90 Mazrui, p.293. 
the force behind the emancipation movement of woman in Russia after the Second World War. Jameelah says that the women of Soviet Union are forced to accept the job offered to her even if it is difficult for her as they are anxious about the future of their husband and children. ${ }^{91}$

Khadija is the only character narrating the past and agonies that they came through. "For fifteen years they tried to build their settlements here, steal our land, deprive us our water and our animals and corps and drive us out but my father and seven elder brothers united the fiercest tribes of the Desert' behind us and we chased them out every time. When l was a young girl, life was good." 92 She points out how she is affected by the colonists. on "The floor of our house was piled high with the bright rugs that my mother had woven herself; we had cushions against the wall, stuffed mattresses to sleep and heavy quilts to keep us warm on cold nights. My mother would cover my dresses with colourful embroidery and my brothers had Vine stripped robes to wear. We were blessed by Allah with health and strength. Sickness in our tribe was rare then and our numbers were growing fast but now each year we are fewer and fewer." ${ }^{\prime 3}$ And as Khadija related vivid tales of her past, "Ahmad Khalil could imagine how she spent so much of her childhood among these implements of war, squatting on the floor, busy cleaning, oiling and polishing his collection of captured rifles, revolvers and pistols." 94

Jameelah believes that the East and West are different in regard to their view of education. Jameelah points out that in western type schools, colleges and universities, one finds no love of knowledge for its own sake, became immense degree factories, aspire to a degree for the social and economic advantage of which result is corruption. In a society where money means everything, it can buy a degree, or a bribe to intimidate the examiners to a falling student passing grades, cheating on examinations is to spread. ${ }^{95}$ Despite this fact, such an education is copied by the rest of the world. Jameelah elucidates that in Islamic civilization there is a master, a person is a student in his all life, there is a relaxed atmosphere, there is no economic and financial pressure on the student and when mastery on a subject attained the student went another one. ${ }^{96}$ In Medina Khalifa attains peace when his talent is

91 Jameelah, Kendini Mahkum Eden Batı, p.207.

92 Jameelah, Ahmad Khalil, p.30.

93 Jameelah, Ahmad Khalil, p.30..

94 Jameelah, Ahmad Khalil, p.31

95 Maryam Jameelah, Westernisation and Human Welfare, Crescent, 2008, p.68.

96 Ibid., p.75. 
discovered by a calligrapher and in an intimate atmosphere, he learned the art while in the school of the UNWRA he is regarded as a loss of time trouble maker and savage as he rejected to sit on the floor rather than on the desk.

Jameelah points out the neglected side of modern education which emphasizes the material gains she calls economic mania. ${ }^{97}$ Khalifa was innocent of ambition or any plans for his future. He was not in search of material success but has the love of knowledge for its own sake. "He never talked about what he would like to be or do when he grew up ... For other children, education was an indispensable tool in their battle for survival but the teachers felt an irresistible attraction and fondness for this one child who valued the acquisition of knowledge solely for its own sake."98

Traditional knowledge loses value as modern education is adopted widely. Jameelah says that "Throughout Asia and Africa, endeavor has been made to eliminate the local cultures. In the minds of new generation seeds of revolt against their own civilizations have been meticulously sowed and through education and mass media, an assassination of their mind and thought has been accomplished." ${ }^{99}$ In a conversation between Ahmad Khalil and Ismail he says that "But father they count for everything while we count for nothing! They know everything. If the only I could go America, England or Germany." 100 When Ahmad Khalil wrote to his father for help, Malak Wahab writes Ahmad Khalil that "They do not give the children any knowledge of our faith according to the needs of today and tomorrow...You must not live in the past. You must believe in progress and have faith in the future."101

Ahmad Khalil is aware of the need for education but rejects cultural imperialism. "But his father had education while he was entirely ignorant and illiterate." ${ }^{102}$ Jameelah opposes the blind imitation of knowledge and equates it with cultural slavery. For her the individual need to know his/her own culture and then the other; yet, he/she must intermingle them in a creative way free from iitation and subjugation of a knowledge to another one. "He wanted to know the history of his own people. His father even awakened in him a keen curiosity to learn about the Jews and the British. He wanted to read the newspapers for himself to be informed about the important events happen-

97 Jameelah, Islam and Modernism, p.51.

98 Jameelah, Ahmad Khalil, p.126.

99 Jameelah, Islam and Modernism, p.26.

100 Jameelah, Islam and Modernism, p.26.

101 Jameelah, Ahmad Khalil, p.236.

102 Jameelah, Ahmad Khalil, p.71. 
ing now which he knew would directly affect his life and his future. And to satisfy this thirst for knowledge, he must learn reading and writing."103

The other piece of globalized western culture is the dress code for men worldwide. By the last quarter of $20^{\text {th }}$ century a man from any culture on Earth could wear a western suit without looking culturally incongruous. The Western standards are now regarded so normal that any male who dresses in his own culture on an international meeting is deemed to be making a political statement. It is regarded as abnormal to be non- Western. So, as "The western suit is now the norm, Islamic dress abnormal and potentially fundamentalist. This is empire of dress." 104

Modern clothes came to symbolize the civilised when the traditional ones to the savage. Malak Wahab takes out his foreign clothes from a locked trunk and contemptuously throws his kaffiyeh and robes at his feet; put on one by one the strange garments- first the underwear, then the shirt, tie, jacket and trousers and finally the socks and shoes on his feet." ${ }^{105}$ When his wife is angry with him Malak Wahab protests that "I only want to show you what a civilised man wears. I always wore this dress before I came here. And this is how you will dress someday when progress transforms the village..."106

The hegemony western type of outfit also can be seen in the dressing of the woman. Asma is representative of traditional Muslim girl attempting to get a modern education. Yet, she does not fit in the frame as she is a veiled girl with a long dress. "When the school for girls opened in the camp, Asma had attended briefly until the other girls in her class began to ridicule her long dress and veil, tease her because she refused to wear the short skirts and go bare-legged and bare-headed like them and taunt her so relentlessly for being 'old-fashioned' and narrow- minded that she could not concentrated her studies and failed the examinations. Her teachers and classmates then conspired against her to make her feel so miserable that she had to quit school before she had even been able to learn to read or write."107

Alcohol is forbidden liquor in Muslim culture. Sheikh visits British Governor to argue with him in most polite way to enforce White Paper forbidding further Jewish immigration and the sale of land without Arab consent, he is offered alcohol. He declines to take any of the forbidden liquors, he was

103 Jameelah, Ahmad Khalil, p.72.

104 Mazrui, p. 17-18.

105 Jameelah, Ahmad Khalil, p.16.

106 Jameelah, Ahmad Khalil, p.16.

107 Jameelah, Ahmad Khalil, p.142-143. 
offered coffee." ${ }^{108}$ Although this prohibition is confined to Muslim societies indeed is practiced by the West, too. "The first state law against alcohol was passed in Maine in 1846" and it spread other states affecting 63 percentage of the population by the end of World War II. ${ }^{109}$ Yet due to the lack of public support for it did not last long. "Just as the Shariah in Nigeria or Iran can only work where there is popular support for it, the Eighteenth Amendment of the United states related to prohibition of alcohol only worked where public opinion was genuinely for temperance and against alcohol. Prohibition at the federal level created resentment among those states that were not against alcoholic drinks, and in large cities in the U.S. where alcohol long become a way of life."110 It seems that two societies converge at some time for welfare of the society. The prohibitions do not necessarily mean tyranny yet the hindrance of the tyranny to the individual and the society.

Mazrui points out that two civilisations also converge in the capital punishment as one of the answers to human depravity. ${ }^{111} \mathrm{He}$ discusses that while the most controversial of Islamic applications of the death penalty relates to sexual offense of adultery, the most controversial of American applications of the death penalty relates to killing the mentally retarded and to the execution of juvenile offenders." 112 Khadija's sister has a premarital relation with a soldier from Negba. She is condemned to death for her transgression and killed as a result. She is condmned not only because of sex before marriage but also for cultural treason. Mazrui states that premarital sex was strongly disapproved in America in the 1920s and there were even laws against sex outside marriage in some states some of which still available on the books but hardly ever enforced. Moreover, he says there were also laws forbidding sex and marriage across the racial divide. Today, it is common. Yet, this is far from Islamic values and some Arab states have even "honor killing" for sexual astray even though this practice is not Islamic. ${ }^{113}$ Jameelah preserves his conviction in death penalty as she believes that it is intended for protecting society and victim rather than subduing the society to the whims of individual.

Ali Mazrui says that though the West carries out the death penalty yet it carries it in subtler ways such as killing overseas or on the air. In Islam, the

108 Jameelah, Ahmad Khalil, p.25.

109 Mazrui, p.295.

110 Mazrui, p.294-95.

111 Mazrui, p.296.

112 Mazrui, p.297.

113 Mazrui, p.293 
welfare of the state and the individual is protected by open laws. The individual knows the punishment for his/her crime as a result. Mazrui criticises that "If Western countries want to kill somebody in some other country, it becomes part of a covert operation. The Central Intelligence Agency or MI5 may take the initiative. The Israelis may fly all the way to Tunis and kill someone in his bed." ${ }^{114}$ Mazrui points out that for the west the sacred is state so it does not refrain from every kind of sanctions and violence to protect it yet it ignores the sacredity of religion and the feelings of its followers. ${ }^{115}$

Another divide between the two civilisation is separation of state and religion. The West loves to dwell on Islam in explaining the problems of the East. "Westerners consider many problems or flaws of the Muslim world are product of Islam and they pride in their societies and governments or their purported secularism." ${ }^{116}$ Mazrui criticises that though the state and church have been separated for more than two hundred years, the policy of the West is not secular. Throughout its history it has only one non-protestant president and though the Jews distinguished themselves in many fields, they have so far avoided for the White House. There is still the danger of arousing anti-Semitic feelings among the Christian fundamentalists. On the other side Islam has protected minority religions with its ecumenicalism. Other religious minorities have later accorded the status of protected minorities (dhimms). ${ }^{117}$ Ahmad Khalil criticises the division ongoing in Palestine and praises the ancient reciprocal society once built by the followers of three religions. He says “...converted to Islam most of the Christian Levantines they found there, and later many of the European crusaders who chose to remain in the country after their defeat and finally merged with them into a single people."118

Science, technology and religion is also placed vis-à-vis one another. Jameelah defends as a result of its historical experience of torture, injustices and restriction and precautions of heresy with violence in medieval periods, from the protestant revolution onwards the deffenders of enlightenment discarded religion from realm and replaced it with science. The civilizations clinging to religion are regarded backward and religion is equated with medievalism. ${ }^{119}$ Roger Bacon defines science as "'Cease to be ruled by dogmas

114 Mazrui, p.108-109.

115 Mazrui, p.98

116 Mazrui, p.249.

117 Mazrui, p.251.

118 Jameelah, Ahmad Khalil, p.2-3.

119 Jameelah, Westernisation and Human Welfare, p.17. 
and authorities!" and to him four sources of ignorance are: "respect for authority, tradition, custom and "the proud unteachableness of our dispositions." And if the world "Overcome these and a world of mechanical power and scientific miracles would open to mankind"120

Jameelah criticizes the idea that mankind can achieve perfect happiness, health, prosperity, beauty, justice and lasting peace through an intelligent, rational application or human reason unaided or sanctioned by any supernatural power. She furthers that while western historians call this age of exploration, indeed, it is better to label it as the age of imperialism as the atrocities and genocides committed had no parallel in past history and previous civilizations..." She says that while Darwin was putting forward his theory, the Europeans were shouldering the white man's burden in Africa and Asia and was embarking on a vast programme of political domination."121 Jameelah states that "Thus modern science is guided by no moral values but naked materialism and arrogance." 122

Jameelah bases its success to materialism and also natural result of all the best minds' and talents' being concentrated on the single goal of achieving the maximum power, speed, efficiency, pleasure, comforts, and conveniences in the shortest possible time. Non-European cultures, including Islamic civilization, never achieved this degree of technological proficiency not because technology was ever rejected on principle, but because the best minds were diverted to other goals considered of greater value. ${ }^{123}$ It is a fact of life that if you want to achieve something badly enough and are willing to sacrifice and subordinate all other considerations, you will naturally outstrip and excel all other peoples in this particular respect. ${ }^{124}$

Ismail rebukes his father that they do not need theologians, poets or philosophers when little children are dying of disease and starvation and their people are enslaved by despotic rulers, by absolete traditions, poverty, illiteracy and hunger. "What we need are dams, factories, big industries and machines of every kind." ${ }^{125}$ Ahmad Khalil does not deny the value of science and technology but rejects their being used as a weapon. . "Their medicines, machines and books are their weapons." ${ }^{126}$ To fill the gap between those so-

120 Jameelah, Westernisation and Human Welfare, p.137.

121 Jameelah, Westernisation and Human Welfare, p.22.

122 Jameelah, Westernisation and Human Welfare, p.139.

123 Jameelah, Islam and Western Civilization, p.138.

124 Jameelah, Islam and Western Civilization, p.139.

125 Jameelah, Ahmad Khalil, p.294.

126 Jameelah, Ahmad Khalil, p.294. 
cieties, Ahmad Khalil recourses to education. "If only I had gone to school, acquired knowledge and tried to study the new sciences when my father gave me the chance." ${ }^{127}$ Then he could learn even from the bitterest adversaries and how he could resist the evil perpetrated by adversaries. ${ }^{128}$ Jameelah says that Islam does not and cannot condemn science on principle." ${ }^{129}$ She expresses that "Were Islam the dominant political, cultural and moral force in the world today as it was in the past, science there would certainly be, as well as progress in every other branch of knowledge but the innovations it introduced and the changes it brings about would be gradual and it would develop along totally different lines and put to entirely different uses in conformity to the spirit of cultural values."130

\subsection{Islam, Zionism and Western Civilisation}

The celebration of race emerging with nation states conflicts with the East and Islam's universalism of people. Islam has envisaged a universalism of people, the Ummah; the U.N has envisaged the universalism of nationstates, the international community. ${ }^{131}$ Mazrui believes that U.N is now a part of the cultural hegemony of the Western world. It is formed by the victors of the World War II. Those victors belonged to one civilisation and a half: Britain, USA, France, and USSR. They are members the U.N.'s powerful security council, which is more powerful and less representative, on the other hand the lower one is called Generally Assembly which is less powerful but more representative. ${ }^{132}$ Thus, the U.N. keeps the peace in lieu with the principles of international law which was child of European diplomatic history and state craft. $^{133}$ The universalism of nation-states favours the Western interests though. As Cleary pointed, it is not domestic factors yet international power politics that are crucial in determining which minority sub-nationalisms are likely to succeed in securing their own state. ${ }^{134}$

Zionism is the product of nationalism. Sharif defines, Zionism as "a complex of beliefs aimed at the practical realization of the 1897 Basle Platform and the Zionists are those who perceive the community known as Jews as a separate national people to be resettled as a sovereign political entity in

127 Jameelah, Ahmad Khalil, p.295.

128 Jameelah, Ahmad Khalil,

129 Jameelah, Islam and Western Society, p136.

130 Jameelah, Islam and Western Society, p.136-137

131 Mazrui, p.274.

132 Mazrui, p.277.

133 Mazrui, p.277.

134 Cleary, p.26-27. 
Palestine in order to establish there an exclusively Jewish-nation-state."135 Kovel regards it as a racist ideology dividing the world into pieces, a catastrophe that Eastern societies are undergoing since the First World War. Pappe argues that in less than two weeks, hundreds of thousands of Palestinians had been expelled from their villages, towns, and cities, the UN 'peace' plan had resulted in people being intimidated and terrorized by psychological warfare, heavy shelling of populations, expulsions, seeing relatives being executed, and wives and daughters abused, robbed, and in several cases raped, most of their houses had gone, dynamited yet there was no international intervention the Palestinians could hope for in 1948, neither they count on outside concern about the atrocious reality involving in Palestine nor help come from UN observers who rushed the country at close hand observing the barbarisations and killings yet were unwilling, or unable to do anything about them. ${ }^{136}$ Ahmad Khalil complains that "And all this had been allowed, nay encouraged by the combined conspiracy of the foreigners so that there could be no compensation, no redress, no appeal, not even the slightest sense of guilt, remorse or shame for the wrong done so that all please for justice fell on deaf ears."137

As nationalism seeks the elimination of different ethnic groups for a homogenized population, the partition of Palestine as stated by Cleary, provided the Zionist to secure itself and to carry out its plan of occupation. Partition provided the ground of conflict which was a necessary condition for the appropriation of the land. He rejects the claims asserting it was hostility that ended in the partition and offers that, actually, it is the partition that has brought about hostility. He claims that partition in such sates triggers conflict and hostility let alone solution. ${ }^{138}$ He elucidates that subsequent to imperial decline or contraction, at a moment that ought ideally to be springtime of national emancipation settler-colonial nation emerges. ${ }^{139}$ Cleary reiterates that the imperial power prepares a lethal scene for nationalisms to clash with each other before departing the scene: "...where an imperial state, suffering from injured national pride and anxious to salvage as much international reputation as possible, comes into conflict with the antagonistic nationalisms of majority and minority communities within a colony, the political climate thus generated can prove an exceptionally lethal one. All

135 Sharif, p.2.

136 Pappe, Ethnic Cleansing of Palestine, p.156.

137 Jameelah, Ahmad Khalil, p. 140.

138 Cleary, p.3.

139 Cleary, p.3 
sorts of catastrophe can occur in the veritable witches' brew of clashing nationalisms generated by such conjunctures." ${ }^{140}$

The Zionists applied various forms of ethnic cleansing, forced population transfer, and coerced assimilation to provide conditions of liberal democratic nationhood. Ahmad Khalil hears from radio after the British mandate ends and the Zionists claims for Palestine which are congruent with national contours. First, "The land of Israel is the birthplace of Jewish people. Impelled by this historic association, Jews strove through the centuries to return to the land of their forefathers and reclaim their statehood."141 Secondly, "In recent decades they returned in large numbers. They reclaimed their wilderness, revived their language, build cities and flourishing farms and industries and established a modern, progressive community with its own economic, social and cultural life. They brought the blessings of prosperity and enlightenment to all inhabitants." 142 Thirdly, the announcing voice says "Our rights are acknowledged by the Balfour Deceleration of November 2, 1917 and reaffirmed by the British mandate delegated by the League of Nations which gave it explicit international recognition...During the World War II, the Jewish people in Palestine made their full contribution to the allies..." ${ }^{143}$ Lastly, the voice mentions Holocaust.

Zionists who take refuge in a three-thousand-year-old idea of exile and expulsion and Biblical teachings telling them the land is promised to them. As stated by Bedlek, "Official history is the recorded history of the empires and the states, documented by historians." ${ }^{144}$ Sand suggests that such a history is invented gradually by historians such as Jost, the first historian of Jewish origin, Graetz, Baron or archaeologist such as Yadin. They treated Old Testament as their handbook and turned it into a national text which would be applied in explaining the current events: They tend to believe for certainty that the Jewish nation has been in existence since Moses received the tablets of the law on Mount Sinai and that they are its direct and exclusive descendants (except for the ten tribes, who are yet to be located). They are convinced that this nation "came out" of Egypt; conquered and settled "the Land of Israel," which had been famously promised it by the deity; created

140 Cleary, p.4.

141 Jameelah, Ahmad Khalil, p.94.

142 Jameelah, Ahmad Khalil, p.94.

143 Jameelah, Ahmad Khalil, p.95.

144 Emine Yeșim Bedlek, magined Communities in Greece and Turkey: Trauma and the Population Exchanges under Atatürk. I.B. Tauris, 2016, p. 64-65. 
the magnificent kingdom of David and Solomon, which then split into the kingdoms of Judah and Israel... ${ }^{145}$

While Palestinian people believe that they have a lifetime over the land and they have a real bond to it, the Zionists recourse to the mythical lines and their persecution in western lands. Ahmad Khalil points out his relationship and bond with the land as native inhabitants of it and interrogates what reasons can bring a foreigner to his land how could it mean the same thing as it is to him. He implores that the land of Palestine is not just a piece of a land; it is a place where he lived a life and the land which he depends on for making a life. "What did they want with this small patch of land upon which generation after generation of his tribe had depended for their existence? How could possibly mean to a foreigner what it meant to him?"146 He regards the Zionists as intruders.

Kovel criticises a two-thousand claim of the Zionists. "All the historiographical exertions by generations of Zionist apologists cannot confer legitimacy on a project in which a variegated people held together by texts and a common faith, and whose actual ethnonational genealogies had been formed all over the map, suddenly decide after two thousand years that they have a real claim on a part of the earth just because it is the center of their Biblical identity. A two-thousand-year-old claim would be laughed out of any secular court, all the more so for the Ashkenazi Jews who comprise the main body of Zionists and have a little discernible link to the ancient inhabitants of Palestine. $^{147}$

Ahmad Khalil asks her mother the reason why do the foreigners come their land, she answers that "They say they have no country. They say they were forced to leave their homes and that they were persecuted and driven out. They tell us they must possess this country as their own because once it belonged to their forefathers..." 148 Jameelah uses indirect speech to depict the Zionist claims that are unproved and only stories they told themselves about themselves. This discourse of exile is refuted by the Jewish historians. Sand indicates that exile is not used in it real sense. In second and third centuries CE "the term galut (exile) was used in the sense of political subjugation rather than deportation, other rabbinical sources refer to the Babylonian exile as the only galut, which they regarded as ongoing, even after the

145 Sand, The Invention of the Jewish People, p.16.

146 Jameelah, Ahmad Khalil, p.2.

147 Kovel, p.37.

148 Jameelah, Ahmad Khalil, p.32. 
fall of the Second Temple. ${ }^{149}$ Another reason, he says, is "the renewed Jewish myth about the exile in fact arose fairly late, and was due mainly to the rise of Christian mythology about the Jews being exiled in punishment for their rejection and crucifixion of Jesus. ${ }^{150}$ And "With the triumph of Christianity in the early fourth century $\mathrm{CE}$, when it became the religion of the empire, Jewish believers in other parts of the world also began to adopt the notion of exile as divine punishment. The connection between uprooting and sin, destruction and exile, became embedded in the various definitions of the Jewish presence around the world. The myth of the Wandering Jew, punished for his transgressions, was rooted in the dialectic of Christian-Jewish hatred that would mark the boundaries of both religions through the following centuries. ${ }^{151}$ Then "The myth of exile began to be slowly appropriated and integrated into Jewish tradition." ${ }^{152}$ Sand points out that the myth must also be adopted by this minority group to overcome the feeling of defeat. Actually, for an oppressed religious minority living in the midst of a hegemonic religious culture, the exile meant a temporal defeat - the fall of the Temple-but the future that would replace it was wholly messianic and totally outside the power of the humbled Jews. Only that future, whether immediate or distant, but precisely lying outside of human time, guaranteed the salvation and perhaps the coming of universal power. ${ }^{153} \mathrm{He}$ adds that The Jews were not forcibly deported from their 'homeland' and there was no voluntarily 'return' to it."154

Jameelah depicts that the clash is not between Judaism and Islam but overlapping interests of the Zionists with that of the imperial powers and that it is anti- Semitism that precipitated the return. As Sharif claims, pogroms against the Jews initiated by Christian Crusade warriors en route to Palestine and that pre-reformation Europe did not look upon the Jews as the Chosen people destined to return to the Holy Land; the Jew if chosen for anything, had been chosen for damnation and also they were generally known as heretics, often branded as the murderers of Christ. ${ }^{155}$ With Protestant reformation, the Biblical Hebrews came to be associated with their co-religionists and thus the idea that the Jews scattered in their present dispersion would

149 Sand, p.133-134.

150 Sand, p.134.

151 Sand, p.134.

152 Sand, p.134.

153 Sand, p.134.

154 Sand, p.134.

155 Sharif, p. 12. 
be re-gathered in Palestine to prepare the ground for the second coming of Christ became popular among Protestant supporters of Bible. ${ }^{156}$ The second coming would be possible only if the Jews were restored to their ancient Homeland. Palestine turned into Jewish land and the Jews transformed to a people who are foreign to Europe far away from their Homeland yet, in due time were to restored to Palestine. ${ }^{157}$ Thanks to Puritanism and its underlying millenarianism in the position of power, the $17^{\text {th }}$ century saw the consolidation of Jewish restoration to Palestine and for the first time in history this idea, which was previously had been regarded as a spiritual event that could be fulfilled with divine intervention, is declared to be performed by human power in 1649: "That this nation of England... shall be the first and the readiest to transport Israel's sons to the land promised to their forefathers." 158 The genuine practice of this idea is not triggered up until the time the interest required, ranging from religious reasons to imperialist ones. George Eliot's Daniel Deronda, regarded by Sharif the summit of Non-Jewish Zionism, speaks "Looking towards a land and polity, our dispersed people in all the ends of the earth may share the dignity of a national life which has a voice among the people of East and West... Then our race shall have an organic centre, a heart, and a brain to watch, guide and execute..." ${ }^{159}$ George Gawler regarded a Jewish Palestine as the only guarantee for Britain's continued influence in the Orient. ${ }^{160}$

Khadija points that the connection of the Zionists to the European powers and the fact that the expulsion is a myth provided by the Zionists. "They migrated to distant countries where they mingled with foreigners and adopted their ways until they lost all resemblance to us. Now there is nothing to choose between them and the British. I cannot see how the Jews of Negba differ from the British at all. "They are just as arrogant, cruel and godless. They have no respect for any religion, not even their own."161

Khalidi says: "The politics of ethnicity within the colonies, in short, was not an innate or autonomous reality but was largely shaped in its modern form in response to the imperial policy." ${ }^{162}$ Jameelah expresses that the Palestinian struggle is not for the land or the sacredness of their race or the

156 Sharif, p. 12.

157 Sharif, p.13.

158 Sharif, p.25-26.

159 Sharif, p.47.

160 Sharif, p.61.

161 Jameelah, Ahmad Khalil, p.34.

162 Jameelah, Ahmad Khalil p.20. 
fact that their forefathers once lived there but they want to get rid of evil, injustice, and subjugation. Yusuf Malik says "We will meet our end with dignity for humiliation and degradation are far worse than death." $163 \mathrm{He}$ points out the value given to humanity in Qur'an saying people to protect themselves and their properties against the intruders and tormentors "war is ordained for you though it may happen that you hate a thing which is good for you or leave a thing which is bad for you." ${ }^{164}$ Sheikh refrains from hatred and wilful tortures to his enemies, he wants to emancipate the land. During the battle between twenty youths belonging to Haganah, the Zionist irregular army, trapped inside the village, surrendered their weapons and allowed themselves to be taken as prisoners. The Sheikh kept them secluded corner of the village and protected them from any harm to enraged. ${ }^{165}$ He chose the way of peace when the colonists of the Negba begged for peace, their plea is accepted and they exchanged their prisoners, their wounded and their dead. ${ }^{166}$ Among the corpses "the Sheikh encountered the body of a young Jewish girl, her clothes ripped off, her eyes gouged out, her nose and ears are amputated." 167 After the culprit was dedected, he was dragged to the village square. His head strucked off with sword by the Sheikh ${ }^{168}$ Sheikh warned the villagers "We are not with the pagan nationalists who glorify any act of cruelty that achieves their end. We fight for Jihad in the cause of Allah and Allah forbids those who waged Jihad to kill woman and children. The law of Jihad forbids us to mutilate the corpses of the fallen enemy. Allah has cursed all warfare for selfish reasons." ${ }^{169} \mathrm{He}$ adds that our rule means absolute justice for Christians and Jews as well as for Muslims. ${ }^{170}$

"Modernity initially came to the fore as a realization of the backwardness of Islamic society in spheres such as politics and military. However, it soon came to encompass all areas of social life as an ideology." ${ }^{171}$ Jameelah believes that modernity is a tool of subjugation, so Palestinians refused to be treated a contagious disease by the doctors coming from Negba as they thought "the

\footnotetext{
163 Jameelah, Ahmad Khalil, p.21

164 Jameelah, Ahmad Khalil, p.115.

165 Jameelah, Ahmad Khalil, p.16

166 Jameelah, Ahmad Khalil, p.21.

167 Jameelah, Ahmad Khalil, p.21.

168 Jameelah, Ahmad Khalil, p.21.

169 Jameelah, Ahmad Khalil, p.21

170 Jameelah, Ahmad Khalil, p.21.

171 Aydin Bayram, "Modernity and Fragmentation of Muslim Community in Response", Anakara Üniversitesi İlahiyat Dergisi, 55:1 (2014), p.72.
} 
injections and the medicine were poisoned. They even attempted to kill the doctors." ${ }^{172}$ The disease signifies the catastrophe that the Palestinian people are experiencing with the arrival of the colonists. They reject being colonized. As they reject their bodies being treated by them; likewise, they reject their land being possessed and controlled by the Zionists.

Akbar S. Ahmad argues that the contemporary civilisation, of which leadership is preserved by the West, is contaminated by materialism and Islam with its notion of a balance between "din", religion, and "dunya", world can provide a corrective and check to the materialism offering instead compassion, piety and a sense of humility instead. ${ }^{173}$ In view of Jameelah modern culture brought with it a disintegrated world and fragmented self compared to a piece of mind provided by Islam to its followers. She claims that modern culture has no compassion to the individual despite all the promise of the reverse. Jameelah believes thatvThomas Edison Alba and Franz Kafka are epitome for the trauma of modern man. The former one provided every kind of comfort, convenience and fun by his new vocal and visual communicational inventories while the latter refuted the idea that these inventions which are misused can throw away the spiritual values aside. ${ }^{174}$ Jameelah says that these inventions made material welfare the target of life yet it placed nihilism, despair, disappointment in place of them and erased the human endeavor, God's mercy, and grace ${ }^{175}$ as it convinced people the nothingness and emptiness of life. She believes that Kafka's novels are extraordinary and scary provisions of Nazi regime and the authoritarian world. ${ }^{176}$ As Kafka himself says, his works are projections of negative elements of his age ${ }^{177}$, Jameelah defends that we feel in Kafka the modern man's loneliness, lovelessness, defencelessness, deprivation of all support, the feeling of loss in a bureaucratic world in which mechanic industrialisation and mechanisation never give up pursuing him. ${ }^{178}$

Khalifa is a disadvantaged and delicate child who is unable to maintain his life in a world of which rule is material. His difference from other people, his purity made him prey to the wicked people around him. Khalifa seldom goes

172 Jameelah, Ahmad Khalil, p.154.

173 Akbar S. Ahmad, Postmodernism and Islam: Predicament and Promise, Routledge, 2003, p.117.

174 Jameelah, Kendini Mahkum Eden Batı, p.291.

175 Jameelah, Kendini Mahkum Eden Batı, p.291.

176 Jameelah, Kendini Mahkum Eden Batı, p.303.

177 Jameelah, Kendini Mahkum Eden Batı, p.307.

178 Jameelah, Kendini Mahkum Eden Batı, p.308. 
out " except to the school where his father taught, which he liked so much he was never absent even for a single day." ${ }^{179}$ He represents all goodness and innocence. Khalifa shares the destiny of his society as it is put by Ghada Karmi "It destroyed their whole society and led to their fragmentation and dispersal" ${ }^{180}$ Khalifa regain tranquillity only when he heard a verse from Qur'an or when treated with affection. Jameelah depicts that Islam protects the weak people of society contrary to the modernity which scatters people to pieces psychologically and leave him/her with a fragmented self.

Yusuf Malik wants to get for him some Quranic Medine; yet, Malak Wahab regards it superstitious. Malik insisted that "It costs us nothing while all the doctors charge for their treatments such high fees even when they know people are sick and cannot pay them." ${ }^{181}$ Surprisingly enough, Malak Wahab sees that "... with this treatment, did indeed Khalifa improve and make much progress. He learned to talk normally and not long afterward, began to walk. He seemed more alert and interested in things going on." ${ }^{182}$ She believes that the faith in oneness of God eliminate ramification of mind and makes mind whole as such a person eliminate all fears except that of Allah and he is impartial to and free from all other powers. ${ }^{183}$ Jameelah believes that though Islam is not only one remedy for illnesses yet Islam is the only and the most effective for healing of psychological illnesses. ${ }^{184}$

Jameelah compares capitalism, socialism and communism and their promise of emancipation with Islam. She believes that they all reserve the wealth, equality, brotherhood for themselves and they only search for the sovereignty of themselves and are inimical to Islam as a rival. She believes that though their offer of equality for all people they have their own agendas detriment to the East and its culture. "The past is dead father! When will you understand that the past is dead. You try to live according to the rigid taboos fit only for primitive people. We cannot look back to past to guide us how to solve the problems that face us today. "185 For him the poverty of the Muslim world is Islam. "It is time for us to wake up! Yes, father I do have faith! I believe that men by their own efforts can raise themselves to higher and higher

179 Jameelah, Ahmad Khalil, p.121.

180 Khada Karmi, Married To Another Man: Israel's Dilemma In Palestine, Pluto Press, 2007, p.17.

181 Jameelah, Ahmad Khalil, p.56.

182 Jameelah, Ahmad Khalil, p.57.

183 Jameelah, Kendini Mahkum Eden Batı, p.184.

184 Jameelah, Kendini Mahkum Eden Batı, p.184.

185 Jameelah, Ahmad Khalil, p.293. 
standards of living! When our people are enslaved by despotic rulers, by obsolete traditions, by poverty, illiteracy and hunger!"186

Jameelah defends that it is a delusion that people believe that no one is dying of hunger in socialist countries; it is just because of this propaganda that people are subsisting in this countries. She says that government shows only the well-off and appropriate places to its visitor. ${ }^{187}$ Indeed, she says, the forefathers of this movement are from rich families who made use of people for their interests and they perpetrated the cruelty to the people in their time. She quotes from the 'Gulag Archipelago' of Alexander Solzhenitsyn in which he indicates the haphazard arrests and detention: Me, why! You have no chance but obey. This is the time that the world collapses on you as every one of us in this world constitute a center when they told you that you are arrested this universe collapse on you by breaking piece by piece. ${ }^{188}$

Jameelah believes that only divinely determined rule can provide the brotherhood and equality between the people of the world. Ahmad Khalil replies that he never says that the offers of modern are bad except for when they are used in the wrong way. He says that "What a blessing this scientists, doctors, teachers and social people would be if they worked to please Allah and really wanted to help us." ${ }^{189} \mathrm{He}$ adds "If they cannot persuade them to do so quickly enough, and then they try to attain what they want by force. Their medicines and books are their weapons. If we stay ignorant and lazy, we cannot but grow weaker and weaker until they enslave us without any resistance and soon disappear."190

Jameelah defends that the significance of man is not his corporal body but his divine spirit in his soul. She criticizes the diminishing of the man to material success ending in greed and image. Ismail works at coke factory and later at oil company and continued to send money regularly and for the first time in Ahmad Khalil's life there was enough to eat."191 Although Ahmad Khalil was satisfied to have enough to eat, Ismail scolds him as he didn't buy clothes for himself with the money he sent. Ahmad Khalil protests that "What uses have I for shoes when I have never worn them before in all my life? The sandals I bought are very good and quite enough." ${ }^{192}$ Yet, Ismail

186 Jameelah, Ahmad Khalil, p..294

187 Jameelah, Kendini Mahkum Eden Batı, p.243.

188 Jameelah, Kendini Mahkum Eden Batı, p.243.

189 Jameelah, Ahmad Khalil, p.204.

190 Jameelah, Ahmad Khalil, p.204-205.

191 Jameelah, Ahmad Khalil, p.261.

192 Jameelah, Ahmad Khalil, p.263. 
who gives importance to image above else says "I am ashamed if my father is mistaken with a beggar." 193 Jameelah indicates how the capitalist world defined the value of people confined to its corporal body. Ismail has no value for abstract values but it is the concrete ones that make sense to him. Ismail has no value for the remedy coming from mutual love and support. He wants to take his father to hospital but when Rashid says l will come and take care of you he rejects "That will not be necessary. You are neither a doctor nor a nurse." ${ }^{194}$ Jameelah depicts that the Western capitalism giving precedence to material is sovereign in the world and the East is not free from it. She criticises the Saudi Arabian people. Comparing the persecuted people with Saudis, who reaped the benefits of the oil industry, Ahmad Khalil felt a closer kinship with persecuted people of Turkestan. ${ }^{195}$

\subsection{Modernity and Islam}

Jameelah deals the clash modernity created in regard to nature and physical world in general sense. While previously nature was revered as a creation of God, with modernity the West regards it as an enemy to be conquered and it make man master and possessor of nature. It became a tool of dominance of man over environment. ${ }^{196}$ She stresses the influence of nature over people and the harmony between the two. It offers healing, guidance for the traditional societies. "As soon as the children had sufficiently convalesced, Yusuf Malik and his cousins were given the responsibility of caring the flocks of sheep and goats in the hope they would fully recover their health."197 Jameelah says that "the posture was the boundary between Iraq al Manshiya and Negba"198 "Far more than five centuries, ever since the inception of European Renaissance the rise of the Industrial Revolution, western man has regarded nature as an enemy to be exploited, dominated, conquered and destroyed." ${ }^{199}$ Yet, it is a place "There the children had plenty of time to play in the open, pure fresh air, and could run and shout carefree with each other from morning to night and drink as much as milk they wanted."200

Kovel bases this deterioriation of relationship on the rupture between man and nature ending split in human mind and also split from the environ-

193 Jameelah, Ahmad Khalil, p.263.

194 Jameelah, Ahmad Khalil, p.263.

195 Jameelah, Ahmad Khalil, p.193.

196 Jameelah, Ahmad Khalil, p.193.

197 Jameelah, Ahmad Khalil, p.57.

198 Jameelah, Ahmad Khalil, p.58.

199 Jameelah, Ahmad Khalil, p.94.

200 Jameelah, Ahmad Khalil, p.58. 
ment. ${ }^{201}$ Jameelah compares the harmony between man and nature and the respect for the soil in an agricultural society which is in contrast to the modern industrial society. Ahmad Khalil takes pleasure in dealing with the soil as like other inhabitants of it. Although Iraq al- Manshiya is an arid place they know how to deal it and they take pleasure in what they produced. "Then Ahmad Khalil looked down with pride and happiness at his handiwork. The plant he was tending every day was growing straight and tall, their green leaves crisp, bright and thriving with health and vigor..." ${ }^{202}$

Jameelah indicates the connection of natives to their lands that the colonists are not able to realize. For instance, she says, "when the European started to colonize America, the aboriginal Indians were horrified by the in contempt they displayed towards the natural environment, recklessly hacking down and destroying vast forest wealth with axe and fire, leaving the denuded land to become eroded and useless within a very short time and ruthlessly exterminating scores of species of wild animals and birds." 203 "Iraq al Manshiya was on the edge of desert beyond which stretched as far as the eye see, the most arid desolate land, yet the fellaheen knew how to coax their crops to grow where the stranger would not believe that anything could live, for any soil that could yield even the most meagre sustenance, was guarded by them with the most meticulous care." ${ }^{204}$ Jameelah states that the colonists could not understand the natives' commitment to their soil; she quotes the chief of Creek, Eneah Emathia, who says that white colonists cannot understand the feeling of people who love their country. Upon leaving their land and they bid farewell to it by touching every leaf, tree, rock, river; the colonist watching them leave the place with revel. ${ }^{205}$

Jameelah depicts how this view of nature deteriorated the ecosystem in Palestine. Palestinian people are inflicted with the shortage of water. Because of shortage of water "The three children obediently performed their ablution with a mixture of sand and dust..." ${ }^{206}$ In order to retain the remaining sources at hand, "The well was heavily guarded day and night by more than a dozen fierce-looking tribesmen, their rifles always in hand, their kaffiyehs wrapped around their heads only their black eyes could be seen... peering across the

201 Kovel, p.15.

202 Jameelah, Ahmad Khalil, p.78.

203 Jameelah, Islam and Western Civilization, p.95.

204 Jameelah, Ahmad Khalil, p.78.

205 Jameelah, Ahmad Khalil, p. 73.

206 Jameelah, Ahmad Khalil, p.274. 
desert horizon in the direction of Negba for any sign of danger."207 The water is so meager that animals cannot find water in their environment. "Ahmad Khalil found an emaciated dog blocking the doorway, painting with his dry cracked tongue out in an agony of thirst. Ahmad Khalil filled a cracked discarded bowl of water for it to drink." As a result of destruction of nature the animals are desperate. Ahmad Khalil searched the room found some scraps of stale bread and a few bones flung on the floor the previous night and threw them to it the dog stared at the boy with sad eyes before he grabbed the heavy shovel and run outside towards the field." ${ }^{208}$ She explains that only a reverent attitude towards nature is the only remedy to stop air and water pollution compared to short-term commercial profit. ${ }^{209}$ She believes that as modern science is devoid of the sensitivity and sentience towards man and nature it becomes a weapon turned against humanity. ${ }^{210}$

Jameelah implies the tie of the modern culture with ancient Greek that celebrates the beauty and youth. Though in Islam the health of the body is important its exposure is forbidden. The ruling elite ashamed of the old was transforming the city from old to the new "so much so that plans were already underway to construct in Medina an elaborate sports stadium in order to encourage love for athletics and games among the youth." ${ }^{211}$ To form the imagined republic, it is set out to beautify the country at the expense of the poor that are striving for a life. The states of the East need prestige which makes the plea of the poor inaudible. "They developed a passion for tearing down old buildings, even those still in fair condition, in order to widen and straighten the streets and make way for ones in conformity to the fashionable foreign styles." ${ }^{212}$ All off these are made to modernize and beautify the city.

Jameelah believes that modernity created nuclear family and that idea is in conflict with the big family celebrated by the Eastern societies. She says in the West kinship groups larger than the immediate family plays an insignificant role. Instead, there are social, cultural and economic or political groups which in turn weaken or obliterate the filial ties. ${ }^{213}$ "One of the acutest social problems faced by the West, which is exported to the East thought develop-

207 Jameelah, Ahmad Khalil, p.76.

208 Jameelah, Ahmad Khalil, p.77.

209 Jameelah, Ahmad Khalil, p.96.

210 Jameelah, Ahmad Khalil, p.190.

211 Jameelah, Ahmad Khalil, p.277.

212 Jameelah, Ahmad Khalil, p.277

213 Maryam Jameelah, Westernisaton and Human Welfare, p.61. 
ment, is the disintegration of family." 214 The social change caused "generation gap" and brought about the rebellion by younger against the older generation, shattered family to pieces. ${ }^{215}$ A. Khalil and his son Ismail are isolated from one another "Awkward in the presence of his mother and Rashid, lsmail felt too much a stranger in his own home even to dare step inside." ${ }^{216} \mathrm{He}$ was bewilderment to them also. Jameelah says that "Once the young bird flies away from the nest, it no longer recognizes his parents. ${ }^{217}$ Ismail could not have recognized him "as so many years before his father seemed to him so alien and ugly in his foreign dress." ${ }^{218}$ He seems to her mother as a stranger. "To her, lsmail was as much a stranger as he was to her husband. She did not trust him. She did not like his arrogant manner or condescending tone of his voice." 219 The disloyalty of children to parents is a source of much heartbreak and grief for both the young and the old who, devoid of family ties, feel betrayed, isolated, lonely and lost." ${ }^{220}$ Jameelah believes that the uprising of a child in a nuclear family is difficult for the parants and these children are in danger of growing up greedy and selfish. Ahmad Khalil "was far more frightened than enraged by the unruly boy who refused to obey but insisted on doing whatever he pleased..." 221 Ahmad Khalil feels helpless about it. "But now the support of tribe and extended clan was gone and all the responsibility fell upon him." ${ }^{222}$ Ismail, who represents the western way of life and individualism is described as "cold, remote, beyond the reach of any parent, indifferent to the plight of others, selfish, greedy and cynical with no respect for the authority of anybody or anything" 223 and as "carefree, without any worry for the future, for he lived entirely in the present."224 "Arrogant, complacent, content and satisfied with himself" 225

Jameelah believes that in traditional societies the ties between the family members are stronger than that of the modern ones. "In traditional civilizations, the importance of filial piety was recognized as essential for the emotional health of individual and the integration of society. All the higher

214 Maryam Jameelah, Westernisaton and Human Welfare, p.58.

215 Maryam Jameelah, Westernisaton and Human Welfare, p.62.

216 Jameelah, Ahmad Khalil, p.262.

217 Jameelah, Westernisaton and Human Welfare, p.62.

218 Jameelah, Ahmad Khalil, p.262.

219 Jameelah, Ahmad Khalil, p.262.

220 Jameelah, Islam and Western Civilization: A Refutation of Modern Way of Life, p.218.

221 Jameelah, Ahmad Khalil, p.16.

222 Jameelah, Ahmad Khalil, p225.

223 Jameelah, Ahmad Khalil, p. 247.

224 Jameelah, Ahmad Khalil, p.247.

225 Jameelah, Ahmad Khalil, p.247 
religions, and especially Islam, place great emphasis on the necessity to preserve at all cost, the sanctity of family life and the ties between the older and younger generations. ${ }^{226}$ She preserves her faith in the necessity of the authority against the depravity of the world and freedom of the individual. Khadja tells Ahmad Khalil how his father and uncle are ridiculed by the children of Negba while they were performing their Salât “... they were surrounded by crowds of children who ridiculed and insulted them, throw handfuls of dust on their heads when they prostrated themselves on the ground, jeering, ' But there is no God! We don't believe God here."227 This event grieves Ahmad Khalil more than the beating his father dealt him for misbehaviour the previous day. ${ }^{228}$

Jameelah believes that "no human societies can exist without authority of some kind. If adultery and homosexuality become general, family life is inconceivable. If parents relinquish their authority over their children and assume the artificial role of "peers", they cease to be parents..."229 She refers to the collective farms of Kiryat Yedidim popularly known as Kibbutz where Mossad carried out a project on a society that defined as "a cooperative community without exploiter and exploited."230 Jameelah explains that these farms are far from fulfilling what they promised. Children who are separated from their families after their birth accepts no authority, mothers complains that they cannot see their children enough, and these children have no respect for their teachers and have racist ideas towards the Oriental Jews and non-Jewish people. ${ }^{231}$ Arab children are thought from an early age to renounce the luxury, how to overcome difficulties and endure the hardship and they learn these in propria persona. ${ }^{232}$

A. Khalil and his family, despite their poverty, in any occasion when they held a feast, no one is spared. Everybody is invited and all people take their share from it. Neither a Jew nor a wild animal is turned down."Sometimes a loaf of bread would fall into the middle of the street from an overloaded truck and at once he would snatch it from the dusty pavement and run home to share the delicacy with his cousins, carefully dividing it into even portions

226 Jameelah, Westernisation Versus Muslims, p.219.

227 Jameelah, Ahmad Khalil, p.35.

228 Jameelah, Ahmad Khalil, p.35.

229 Jameelah, Islam and Western Civilization: p.88.

230 Jameelah, Kendini Mahkum Eden Batı, p.323 (See more on Kendini Mahkum Eden Batı from 323 to 357.).

231 Jameelah, Kendini Mahkum Eden Batı, p.324-325.

232 Jameelah, Kendini Mahkum Eden Batı, p.356. 
for each of them." ${ }^{233}$ And "Little Rashid was repeatedly told that he must not be selfish or greedy, eat only from his side of dish and let the others have their share."234

Jameelah bases the poverty of world in general and Muslim world in particular, to exploitation and injustice and she believes that it can be overcome only when the sources of selfishness and greed are severed at the roots. ${ }^{235} \mathrm{Ja}-$ meelah criticises the individualistic stance to the life and offers that life and responsibility are head to head. Ahmad Khalil had to take care of his brother after his mother's death. "He wanted a playmate, companion and friend yet Allah received this annoying burden. The responsibility of his care ever since he had been weaned fell heavily upon him."236

Jameelah addresses the contestation between the newness and change with respect and loyalty to the past praised by the traditional societies. To her, "In its uncritical worship of change for its own sake and the blind faith that unlimited accelerated innovations are synonymous with social and cultural progress, western civilization is unique...Western civilization alone repudiates old people with contempt because they represent continuity with the past and virtually worships youth and newness." ${ }^{237}$ When Ahmad Khalil mentioned about the Islamic history and the past of his community he is made fun of by his community as they regard it as a thing of past no longer relevant to the present. So, Ahmad Khalil wishes "he had been born a thousand years earlier in the great days of Islam when he could take pride in who he was, where he came from... instead of the humiliation, degradation, defeat after defeat and acutely painful feelings of inferiority which his father and most others he met thought could be brought to an end only by imitating the foreigners and adopting their ways." ${ }^{238}$

Jameelah compares the past products with the current ones and concludes that the contemporary ones are artificial in quality and they are transitory. "The black ivory handle and the richly inlaid scabbard were covered with beautifully hand-carved Quranic inscriptions." 239 The blade symbolizes past, and it is indicative of power and resistance. "It was the sole thing he

233 Jameelah, Ahmad Khalil, p.67

234 Jameelah, Ahmad Khalil, p.65.

235 Jameelah, Islam and Western Civilization: A Refutation of Modern Way of Life, p.41.

236 Jameelah, Ahmad Khalil, p.75.

237 Jameelah, Islam and western Civilization, p.81.

238 Jameelah, Ahmad Khalil, p.75.

239 Jameelah, Ahmad Khalil, p.75. 
owned which envy every boy in the village." ${ }^{240}$ It was indeed a thing of value for since machine-produced factory articles had invaded the bazaar, things of such beauty were no longer made and now rarely to be found"241Yet, she says that the ruthless atomistic, mechanical organisations of modern society cut the very roots of all meaningful and enduring human relationships destroying all social ties without which civilized (and even primitive) human culture cannot survive. ${ }^{242}$ Yusuf Malik finding such a work and giving his son wants to preserve this heritage. Whatever the religion, the occupation or national origin involved, it is vital for people to feel that they are an extension of some kind of tradition. Otherwise they are forced to relate themselves to an historical void. She says that in a traditional society even an educated person knows "the meaning or purpose of existence ${ }^{243}$, he has his position fixed securely in the total scheme. Modern man, with his prime emphasis on individualism, lacking any deep roots in the extended family and feeling of belonging to a community in its genuine sense is cut adrift." ${ }^{244}$ "As a result of the lack of stability his/her existence becomes a hectic search in quest of superficial, fickle and irresponsible pleasures. With unlimited mobility, individuals, cut adrift from family, relations and community, become eternal nomads with no roots anywhere. 245

Jameelah criticizes the idea of progress. This discourse debilitates the members of the traditional societies. It was assumed by the modernizers that the humiliating defeats suffered at the hands of the Europeans were not caused merely by the superior physical force but because something was inherently defective in Islam, its social order, its culture and institutions. ${ }^{246}$ The modernization of traditional peoples has brought in its wake intense self-depreciation, feelings of inferiority and shame for their "oriental" origins." 247 Malak Wahab in quest for dignity he is devoided by the West strikes a defensive attitude and tries to prove that his society has modern sides. "I always wondered why they flocked with their cameras always in hand to take the photos of rickety ruins of the most ancient houses, the refuse- littered alleys and those repulsive blind beggars whining for alms." ${ }^{248}$ He protests that "why

240 Jameelah, Ahmad Khalil, p.75.

241 Jameelah, Ahmad Khalil, p.75.

242 Jameelah, Islam and Western Civilization, p.83.

243 Jameelah, Islam and Western Civilization, p.82.

244 Jameelah, Islam and Western Civilization, p.82.

245 Jameelah, Islam and Western Civilization, p.82.

246 Jameelah, Islam and Modernism, p.10.

247 Jameelah, Westernisation and Muslims, p.32-33.

248 Jameelah, Ahmad Khalil, p.99. 
didn't they ever take photos of the railway station or our beautiful new post office? But no, they only want to see how backward we are!"249

Yet, this stance devoided the East the dignity which has a primary importance. Malak Wahab overcomes this situation only when he began teaching at the refugee camp school. He "spent all his waking hours at the school which gave him a dignity he had never experienced before." 250 "Here he found fulfilment at last. Never in the fifty years of his life had he been so happy. He could not read enough to satisfy the boundless curiosity of his thirsty mind nor the eager inquisitiveness of his students." ${ }^{251}$ His inferiority complex chills him to the bone to such an extent that he evaluates Khadija's marriage with him as an indication of deficiency in her not as an act of opposition to racism. He despices himself and criticices Khadija's father. "He was too happy to find a husband for him, it did not matter to him that I was black and had been a slave." ${ }^{252}$ Cemil Meriç expresses that each civilisation has the equal potential to use intelligence, and the superiority and inferiority is a matter of historical circumstances. The intelligence is available both in the uncivilised, primitive and the developed ${ }^{253}$

\section{CONCLUSION}

The conflict between the West and the East is not a new phenomenon, yet it is a part of process which has gotten worse in the course of history. Contrary to the popular belief, the reasons aggravating the conflict are political and related to power rather than being cultural or related to values. When the reasons behind the conflict are examined injustices, imagined communities, prejudices, inconsistencies, stereotyping, imperialism and colonialism together with racism come to light. Zionism is a product of these agents. It nourishes from them. The discourse formed by the Zionists that they were expelled three thousand years ago, their being supported by the western civilisation, the bad conscience that they carry with them, and lastly the modernity and nationalism paved the ground for the Palestinians to be disregarded, blamed and condemned to inustices. The pretext is that the Palestinians are underdeveloped, they have no right over their land as they are nomads stumbled upon the land of Palestine while the Zionists because of

249 Jameelah, Ahmad Khalil, p.99.

250 Jameelah, Ahmad Khalil, p.99., p.127.

251 Jameelah, Ahmad Khalil, p.99.

252 Jameelah, Ahmad Khalil, p. 52.

253 Cemil Meriç, Kültürden İrfana, İletişim, 2017, p.57. 
the persecution they have experienced on the foreign lands and once promised to "Canaan" with the help of power Jews, an army and Western civilisation behind them has the right. Such a discouse will be laughed at every court, yet their opponents being powerful and having the support of an imperial power makes Palestinians voice and plea for justice inaudible. There is a bad conscience behind this trauma. Ahmad Khalil with his life story indicates that the enemies are not people, culture and values yet the enemies are terrorism, illiteracy, ignorance, poverty, wars, violence, the loss of values, the evil, massacres, prejudices, enmities, racism, oppression, and environmental problems. Leaving behind prejudices and the rivalry with tricks and adoption of common sense and act in with truth in a brave way will transform the conflict to co-existence. Despite the borders that have been created nevertheless all people living on the world are one family having members who have different tastes and beliefs. Their difference does not diminish them. As it is expressed by Ahmad of Jerusalem, "What I am struggling for now is to see this universe as without borders, so that people can move without anyone stopping you to ask where are you from, where are you going, who are you, Christian, Muslim or Jew? ... This is what I believe-that all these conflicts are monstrous and cannot be justified at all. We are fighting each other as human beings... How can I believe that this land is mine and that land is his since we came naked into this world? And since I will leave it naked and will take nothing with me. ... We are all human beings. If we believe in God, then God created us all. I do not believe God is racist... Nature is all his creation; we are all a product of nature, and this is not our choice but a fact. The only real difference is how you present yourself to your community, and the good you do for your community. That is how we should discriminate between people... Not just their local community but also the world community. Yes, the whole world. I am not talking about internationalism when I say this because internationalism is a way to control others. If you say I am Arab then you set yourself off against Europe or America. If I say I am from France, then what about Britain, and if I say I am from Britain, then what about Belgium? That's keeping borders between people. I believe that all the people in the world are one family, that we are all brothers and sisters. ${ }^{254}$

254 Kovel, p.227-228. 


\section{BIBLIOGRAPHY}

AKBAR S. Ahmad. Islam and Postmodernism: Promise or Predicament, Routledge, 1992. ARTUN, Ali. Contemporary Art and Culturalism, İletişim Publication, 2013.

BEDLEK, Emine Yeșim. Imagined Communities in Greece and Turkey: Trauma and the Population Exchanges under Atatürk. I.B. Tauris, 2016.

CHAKRABARTY, Dipesh. Avrupayı Taşralaştırmak: Postkolonyal Düşünce ve Tarihsel Farklılık, Boğaziçi Üniversitesi Yayınevi, 2012.

CHOMSKY, Noam, and PAPPE, Ilan. GAZA IN CRISIS: REFLECTIONS ON ISRAEL'S WAR AGAINST THE PALESTINIANS, Haymarket Books Chicago, Illinois, 2010.

CLEARY, Joe. Literature, Partition, and the Nation-State, Cambridge University Press, 2014.

CUBITT, Geoffrey. History and Memory, Manchester University Press, 2007.

DAVUDOĞLU, Ahmet. “Fukuyama'dan Huntington'a: Bir Bunalımı Örtme Çabası ve Siyasi Teorinin Pragmatik Kullanımı" in Samuel P. Huntington v.d. Medeniyetler Çatışması, derleyen Murat Yılmaz, Vadi 1995.

DIRLIK, Arif. The Postcolonial Aura: Third World Criticism in the Age of Global Capitalism, Boğaziçi, 2010.

- "Culturalism as Hegemonic Ideology and Liberating Practice." Cultural Critique 6 (1987).

DUSSEL, Enrique. "Europe, Modernity, and Eurocentrism", Nepantla: Views from South, Duke University Press, 2000.

EAGLETON, Terry. After Theory, London, Penguin,2004.

ESPOSITO, John L. The Islamic Threat, Oxford University Press, 1999.

FANON, Frantz. Yeryüzünün Lanetlileri, Versus, 2007.

GREGORY, Derek. The Colonial Present, Blackwell, 2004.

HAMENEİ, Ayetullah Seyyid Ali. Özgürlüğünü Bekleyen Toprak: Filistin, Feta Yayıncılık, 2015.

Hobsbawm, Eric. Nations and Nationalism Since 1780: Programme, Myth and Reality, Cambridge University Press, 1992.

HOBSON, John M. The Eastern Origins of Western Civilization. Cambridge U.P. 2004.

JHA, Prem Shankar. The Twilight of the Nation State Globalisation, Chaos and War, Pluto Press, 2006.

HOURANİ, H.Albert Batı Düşüncesinde İslam, İstanbul; Pınar Yayınevi, 1996.

HUNTINGTON, Samuel P. The Clash of Civilizations and Remaking of World Order, Penguin Books, 1996.

PAPPE, Ilan. https://www.youtube.com/watch?v=buhpHTGAITE.

PAPEE, Ilan. HILAL, Jamil. Across the WALL: Narratives of Israeli-Palestinian History I.B.Tauris, 2010.

JAMEELAH, Maryam. Westernisation and Human Welfare, Crescent, 2008.

-Garp Metaryalizmi Karşısında İslam translated by Kemal Kuşçu, Çile Yayınları, 1976(3.Baskı). 


\section{BINGÖl ARAȘTIRMALARI DERGISi}

- Quest for the Truth: Memoirs of Childhood and Youth in America,(1945-1962), New Delhi, 1992.

-Ahmad Khalil The Story of an Arab Refuge, published by Muhammed Yusuf Khan and Sons, revised version, 2000.

-Westernisation Versus Muslims (Cultural SLavery is Inseparable from Political Slavery, Westernisation A Panoramic View), Muhammed Khan And Sons, 2000.

-Kendini Mahkum Eden Batı, Kültür Basın Yayın Birliği (Cild:1), 1990.

-Islam and Western Civilization: A Refutation of Modern Way of Life, Adam Publishers \& Distributors, $3^{\text {rd }}$ Edition (1990).

-Islam and Modern Man, Crescent (1989).

- "Is Western Civilization Universal”, Lahore, Pakistan, 1969.

- Islam and Orientalism, Seçkin Publication,1989.

- "Islam and Modernism", Sant Nagar, Lahore, Pakistan, 1968.

- "Islam and the Muslim Woman Today", Taj Company, Jama Masjid, Delhi, 1982.

- "Islam Versus the West", Taj Company, Jama Masjid, Delhi, 1982.

"Modern Technology and the Dehumanization of Man", Crescent Publishing, Delhi, 1982.

- "The Generation Gap its Causes and Consequences" Muhammad Yusuf Khan, Sant Nagar, Lahore. Pakistan, 1989.

- “Western Imperialism Menaces Muslims”, Crescent Publishing, Delhi, 1977.

Israel Palestine: The Black Book. Edited by Reporters without Borders, Pluto Press, 2002.

KABBANI, Rana Europe's Myths of Orient; Devise and Rule, MacMillan Press: London, 1986.

KABBANI, Rana Letter To Christendom, Virago, 1989.

KADA, Kharmi. Married To Another Man: Israel's Dilemma In Palestine, Pluto Press, 2007.

KALIN, İbrahim. Ben Öteki ve Ötesi, İnsan Yay. İstanbul. 2016.

KHALIDI, Rashid, The Iron Cage: The Story Of The Palestinian Struggle For Statehood, One World Publications, 2006.

KHWAJA, Usman Zafar. Islam and the West into a New Era?, usmanzafarkhawaja (Standard Copyright License), 2012.

KOVEL, Joe. Overcoming Zionism: Creating a Single Democratic State in Israel/Palestine, Pluto Press and Between the Lines, 2007.

LANE, Richard. The Postcolonial Novel, Polity Press,2006.

MAZRUI, Ali. Islam Between Globalization and Counterterrorism, Oxford, James Currey, 2006.

MAJEED, Anouar. "Can the postcolonial Critic speak? Orientalism and Rushdie Affair," Cultural Critique No. 32 (Winter, 1995-1996).

MAJEED, Anouar. Unveiling Traditions: Postcolonial Islam In a Polycentric World, World pub., 2000. 


\section{BINGÖl ARAȘTIRMALARI DERGISi}

Meriç, Cemil. Kültürden İrfana, İletişim, 2017.

SAID, Edward W. Orientalism, Vintage Books, New York. 1994.

-Culture and Imperialism. New York; Vintage.1994.

- The Question of Palestine, Vintage Book, 1992.

- Covering Islam, Vintage eBook, 1997.

SAKEENAH, Maryam. “Maryam Jameelah: 'With An Eyeful of Madina's Dust', “http:// www.mybitforchange.org/2012/maryam-jameelah/

SHARIF, Regina. Non- Jewish Zionism: Its Roots In Western History, Zed Press, 1983.

SAND, Shlomo.The Invention of Jewish People, Verso, 2009.

SARDAR AND DAVIES, Distorted Imaginations: Lesson from the Rushdie Affair, Grey Seal Books, 1990.

ŞAYEGAN, Daryuş. Batı Karşısında Asya, Ağaç Kitabevi Yayınları, 2005.

ŞENEL, Şevket Adnan. "Muzaffer ÖZDAĞ ile Mülakat: Medeniyetler Çatışması Üzerine" in Samuel P. Huntington v.d. Medeniyetler Çatışması, der: Murat Yılmaz, Vadi, 1995.

TOPRAK, Binnaz, "Huntington, Batı' nın Önyargılarını Yansıtıyor” in Samuel P. Huntington v.d. Medeniyetler Çatışması der: Murat Yılmaz, Vadi, 1995.

TYSON, Lois. Critical Theory Today, Routledge, 2006(sec. Edit.).

WASIF, Shadid and van KONINGSVELD Pieter S., "The negative image of Islam and Muslims in the west: Causes and solutions", Religious freedom and the neutrality of the state: the position of Islam in the European Union. Leuven: Peeters (2002).

YALÇıN, Kemal. Haymatlos: Dünya Bizim Vatanımız, Türkiye İş Bankası Yayınları, 2016.

YILMAZ, Murat. Samuel P. Huntington V. D. Medeniyetler Çatışması, Vadi Yayınları, 1995(1. Basim).

Liddle, Joanna \& RAI, Shirin (1998) "Feminism, imperialism, and Orientalism: the challenge of the 'Indian woman', Women's History Review, p.497

WASIF, Shadid and KONINGSVELD, Pieter S. "The negative image of Islam and Muslims in the west: Causes and solutions", Religious freedom and the neutrality of the state: the position of Islam in the European Union. Leuven: Peeters (2002): 174-196.

MAJID, Anouar. "Can the postcolonial Critic speak? Orientalism and Rushdie Affair", Cultural Critique No. 32 (Winter, 1995-1996).

AL-SAIDI, Afaf Ahmed Hasan. "Post-colonialism Literature the Concept of self and the other in Coetzee's Waiting for the Barbarians: An Analytical Approach", Journal of Language Teaching and Research, Vol. 5, No. 1, pp. 95-105, January 2014.

Infeld, Avraham on History and Memory, https://www.youtube.com/watch?v=gRmG-aRBsPI. 
